\title{
Worldwide trends in gastric cancer mortality (1980-2011), with predictions to 2015, and incidence by subtype
}

\author{
Ana Ferro ${ }^{a}$, Bárbara Peleteiro ${ }^{\mathrm{a}, \mathrm{b}}$, Matteo Malvezzi $^{\mathrm{c}}$, Cristina Bosetti $^{\mathrm{c}}$, Paola Bertuccio ${ }^{\mathrm{c}}$, \\ Fabio Levi ${ }^{\mathrm{d}}$, Eva Negri ${ }^{\mathrm{c}}$, Carlo La Vecchia ${ }^{\mathrm{c}, \mathrm{e}}$, Nuno Lunet ${ }^{\mathrm{a}, \mathrm{b}, *}$ \\ ${ }^{a}$ Institute of Public Health of the University of Porto (ISPUP), Rua das Taipas $n^{\circ}$ 135, 4050-600 Porto, Portugal \\ ${ }^{\mathrm{b}}$ Department of Clinical Epidemiology, Predictive Medicine and Public Health, University of Porto Medical School, Al. Prof. Hernâni Monteiro, \\ 4200-319 Porto, Portugal \\ ${ }^{\mathrm{c}}$ Department of Epidemiology, IRCCS - Istituto di Ricerche Farmacologiche Mario Negri, Via La Masa 19, 20156 Milan, Italy \\ ${ }^{\mathrm{d}}$ Cancer Epidemiology Unit, Institute of Social and Preventive Medicine (IUMSP), Lausanne University Hospital, Rte de la Corniche 10, \\ CH-1010 Lausanne, Switzerland \\ ${ }^{\mathrm{e}}$ Department of Clinical Sciences and Community Health, University of Milan, Via Festa del Perdono 7, 20122 Milan, Italy
}

Available online 17 March 2014

\section{KEYWORDS \\ Gastric neoplasms \\ Cardia \\ Incidence \\ Mortality \\ Trends}

\begin{abstract}
Gastric cancer incidence and mortality decreased substantially over the last decades in most countries worldwide, with differences in the trends and distribution of the main topographies across regions. To monitor recent mortality trends (1980-2011) and to compute short-term predictions (2015) of gastric cancer mortality in selected countries worldwide, we analysed mortality data provided by the World Health Organization. We also analysed incidence of cardia and non-cardia cancers using data from Cancer Incidence in Five Continents (2003-2007). The joinpoint regression over the most recent calendar periods gave estimated annual percent changes (EAPC) around $-3 \%$ for the European Union (EU) and major European countries, as well as in Japan and Korea, and around $-2 \%$ in North America and major Latin American countries. In the United States of America (USA), EU and other major countries worldwide, the EAPC, however, were lower than in previous years. The predictions for 2015 show that a levelling off of rates is expected in the USA and a few other countries. The relative contribution of cardia and non-cardia gastric cancers to the overall number of cases varies widely, with a generally higher proportion of cardia cancers in countries with lower gastric cancer incidence and mortality rates (e.g. the USA, Canada and Denmark). Despite the favourable mortality trends worldwide, in some countries the
\end{abstract}

\footnotetext{
* Corresponding author at: Department of Clinic Epidemiology, Predictive Medicine and Public Health, University of Porto Medical School, Al. Prof. Hernâni Monteiro, 4200-319 Porto, Portugal. Tel.: +351 225513652.

E-mail address: nlunet@med.up.pt (N. Lunet).
} 
declines are becoming less marked. There still is the need to control Helicobacter pylori infection and other risk factors, as well as to improve diagnosis and management, to further reduce the burden of gastric cancer.

(C) 2014 Elsevier Ltd. All rights reserved.

\section{Introduction}

Gastric cancer is the fourth most common cancer and the second leading cause of cancer deaths worldwide, despite its incidence and mortality have been appreciably declining for several decades [1-3]. The fall in gastric cancer is mainly due to the decline in the prevalence of Helicobacter pylori $(H$. pylori) infection and tobacco smoking, and to the improvements in food preservation and diet [4]. However, the patterns in gastric cancer trends vary substantially across geographical regions $[3,5]$, reflecting a heterogeneous distribution of the factors associated with gastric cancer incidence, survival and mortality, with time, over birth cohorts and across countries (Fig. 1).

The burden of gastric cancer remains very high in several countries from Asia, Latin America and Central and Eastern Europe, whereas in North America and in most Western European countries it is no longer a common cancer $[1,3,6]$. Incidence rates showed differences according to tumour topography [7,8], with upward trends in cardia incidence $[9,10]$. The validity of data on gastric cancer subtypes is, however, open to discussion [11].

To monitor recent trends in gastric mortality worldwide, and to compute short-term predictions for selected countries, we analysed mortality data provided by the World Health Organization (WHO) [12]. We also analysed the incidence of cardia and non-cardia cancers in selected countries worldwide, using available data from Cancer Incidence in Five Continents (CI5) [6].

\section{Methods}

\subsection{Gastric cancer mortality}

We derived official data for gastric cancer mortality in 41 European countries and in 21 countries from other areas of the world from the WHO online database, for the period 1980-2011 [12].

In Europe (defined as the WHO European region), we considered a few countries of the former Soviet Union (i.e. Armenia, Azerbaijan, Georgia, Kazakhstan, Kyrgyzstan and Uzbekistan), even though some of them had low national coverage and completeness. For the American continent, 13 countries with satisfactory death certification coverage and completeness were included (i.e. Canada, United States of America (USA), Argentina, Brazil, Chile, Colombia, Costa Rica, Cuba, Ecuador, Mexico, Puerto Rico, Uruguay and Venezuela). Mortality data from gastric cancer were also available for four Asian countries (i.e. Hong Kong, Japan, the

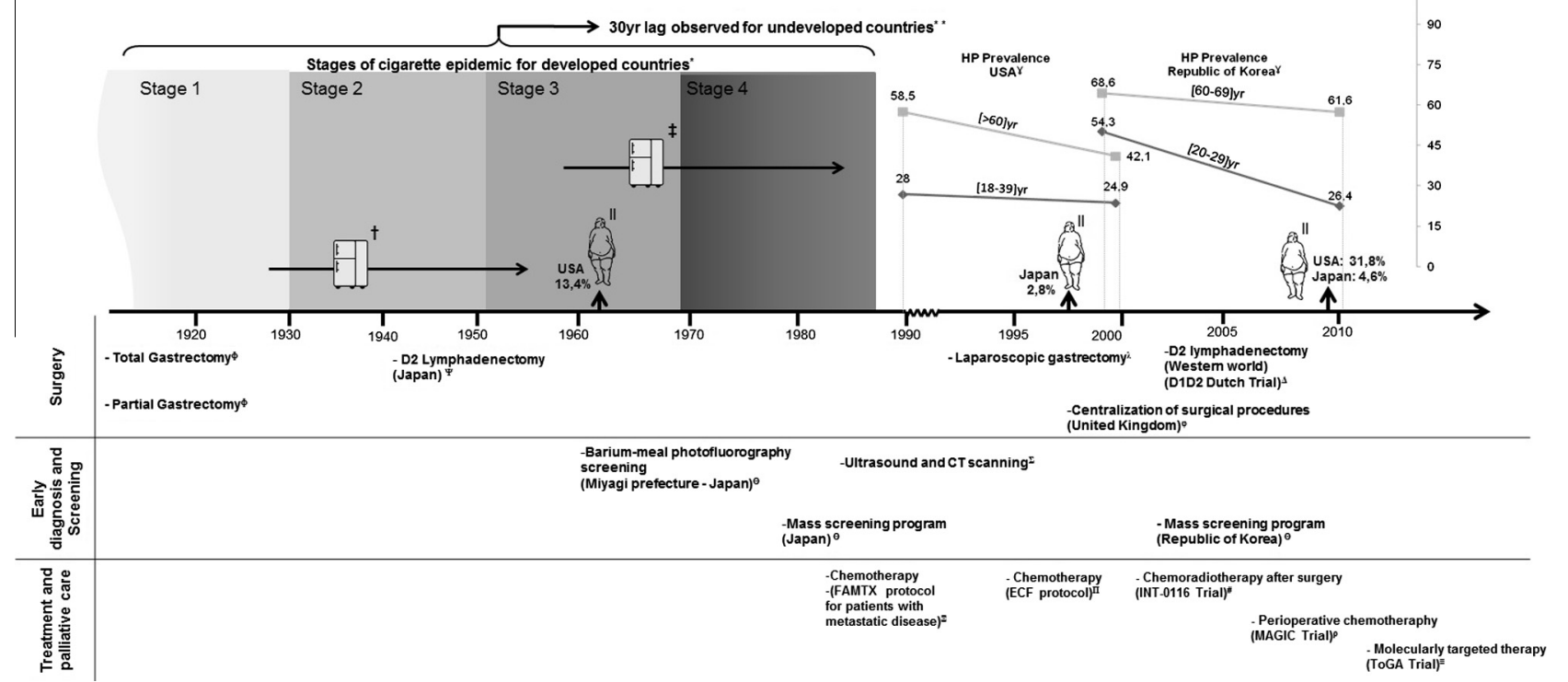

Fig. 1. Chronology of landmarks with potential impact on gastric cancer incidence, survival and/or mortality. ${ }^{*}$ - Stages of cigarette epidemic for developed countries [60], ${ }^{* *}-[61], \dagger-$ Dissemination of food refrigeration in the United States [62], $\ddagger-$ Dissemination of food refrigeration in Japan [62], $\|$ - Prevalence of obesity [63-65], $\mathrm{\gamma}$ - Prevalence of Helicobacter pylori infection [27,32,33], $\phi-[66], \Psi-[66], \odot-[67], \Xi-[68], \Sigma-[69]$, $\lambda-[70], \Pi-[71], \varphi-[47], \#-[47], \Delta-[72], \rho-[45], \equiv-[46]$. 

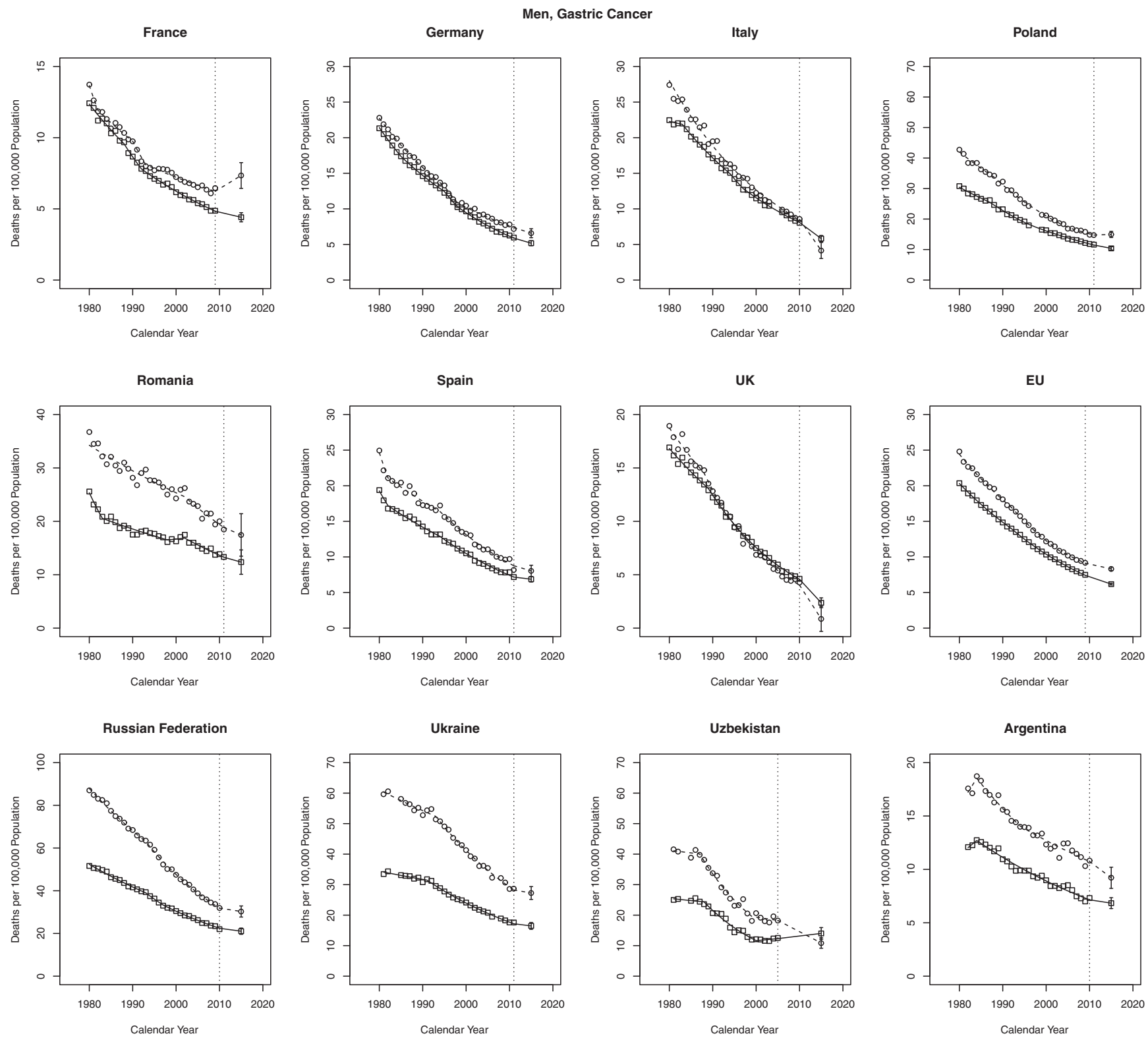

Fig. 2. Joinpoint analysis for gastric cancer mortality in selected European countries, in the European Union, and in other world countries, at all ages $(\square)$ and truncated at 35-64 years $(\bigcirc)$ for men, 1980-2011 (when available) and predictions for 2015 (with the corresponding 95\% confidence interval).

Republic of Korea and Singapore), for one African country (Mauritius), and for Australia and New Zealand.

Since three different Revisions of the International Classification of Diseases (ICD) were used in the period considered, we extracted, as applicable, those corresponding to the codes A047 (ICD-8) [13], B091 (ICD9) [14] and C16 (ICD-10) [15]. Population figures based on official censuses were also obtained from the WHO database [12].

We computed country- and sex-specific mortality rates for each 5-year age group and calendar period, and derived age-standardised rates by the direct method, using the world standard population, for all ages and truncated at 35-64 years. For the European Union (EU) as a whole, rates were computed using the aggregated number of deaths in its 27 member states as defined in January 2007, and the corresponding populations; Cyprus was excluded as mortality data were only available for a limited number of recent years. Interpolation of missing data was made only for the construction of the EU rates; when data were not available for a country, the nearest available figures were replicated (i.e. generally those of the previous or subsequent year).

In order to identify significant changes in mortality trends for selected countries, we performed joinpoint regression analysis allowing for up to three joinpoints [16]. For each of the identified trends, we computed 

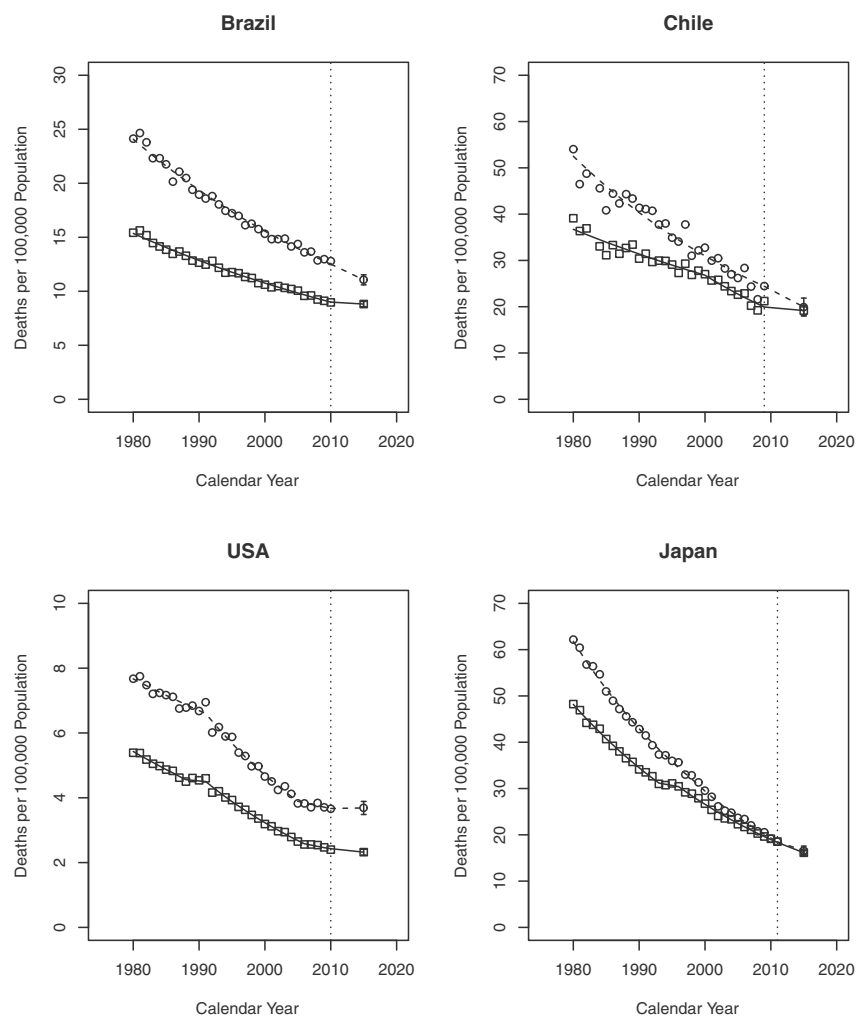
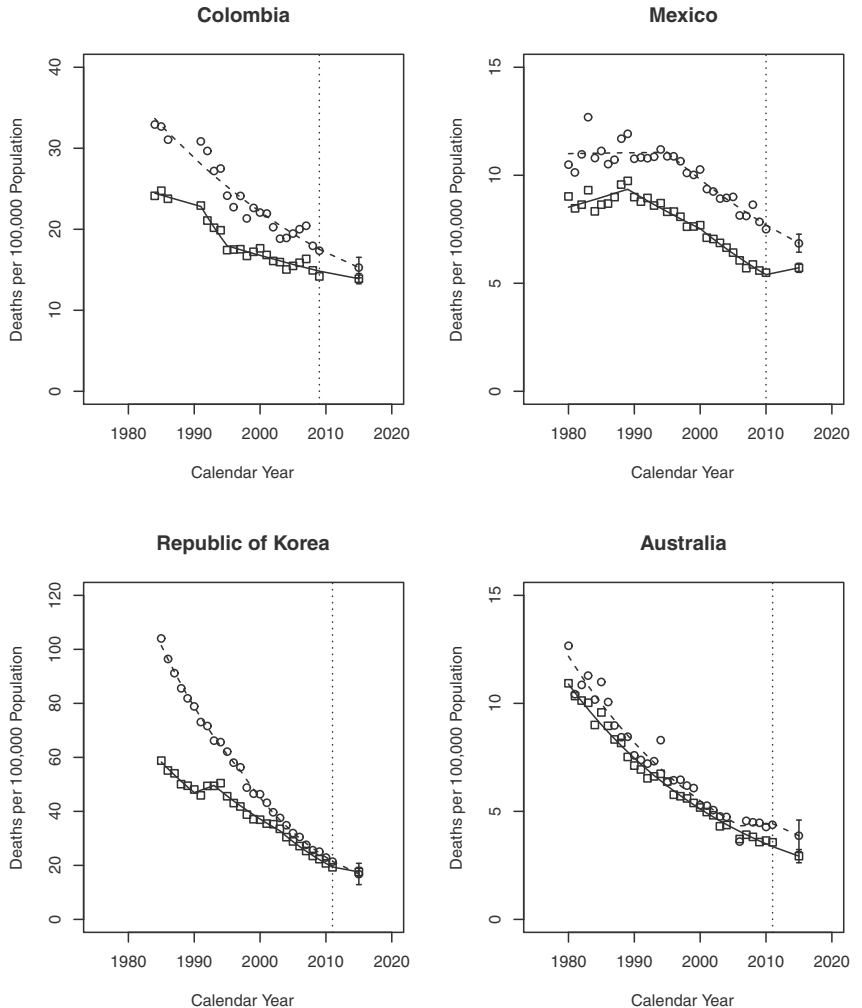

Fig 2. (continued)

the estimated annual percent change (EAPC) by fitting a regression line to the natural logarithm of the rates using calendar year as a regression variable. The average annual percent change (AAPC), based on an underlying joinpoint model, was also calculated, and it was estimated as the geometric weighted average of the EAPCs, with the weights equal to the lengths of each time interval segment [17].

For the EU as whole and for selected countries from different world regions, we computed predicted numbers of gastric cancer deaths and rates for the year 2015 . These were derived by fitting a joinpoint model to each 5-year age-specific number of certified deaths, assuming a Poisson distribution, in order to identify the most recent trend segment [18]. Then, a linear regression was performed on mortality data from each age group over the time period identified by the joinpoint model as the most recent trend, in order to compute the predicted age-specific number of deaths, the corresponding 95\% confidence intervals (CIs) and prediction intervals (PIs). The PI is a measure of uncertainty that accounts for the random nature of future predicted values, by adding an extra term in the standard error calculation [19]. We computed age-standardised mortality rates (and the corresponding 95\% CIs and PIs) for 2015 using the predicted population data, obtained from Eurostat [20], whenever available, and from The United Nations' Department of Economic and Social Affairs [21], otherwise.

\subsection{Gastric cancer incidence}

We obtained incidence data from the most recent volume of CI5 - volume X [6], corresponding to the period 2003-2007, and we considered gastric cancer incidence by topography defined as cardia $(\mathrm{C} 16.0)$, non-cardia (fundus, C16.1; body, C16.2; pyloric, C16.3; pylorus, C16.4; lesser and greater curvature, C16.5-6) and other parts (C16.8-9) [15]. When data from more than one cancer registry were available in the same country, we added the number of incident cases from all registries.

We mapped the proportion of cardia and non-cardia cancers among those with known topography, by sex, using ArcGIS [22]. The analysis was restricted to countries with at least $20 \%$ of the cases with topography defined as cardia or non-cardia, and a minimum of 100 cases in these topography groups.

\section{Results}

\subsection{Trends in mortality}

The findings from the joinpoint regression over the period 1980-2011 in the 19 largest countries and in the EU as a whole are given in Figs. 2 and 3 and in Supplementary Table 1.

Trends were significantly downward in all countries, for both men and women. In the EU as a whole, EAPCs over the most recent period were $-3.7 \%$ in 

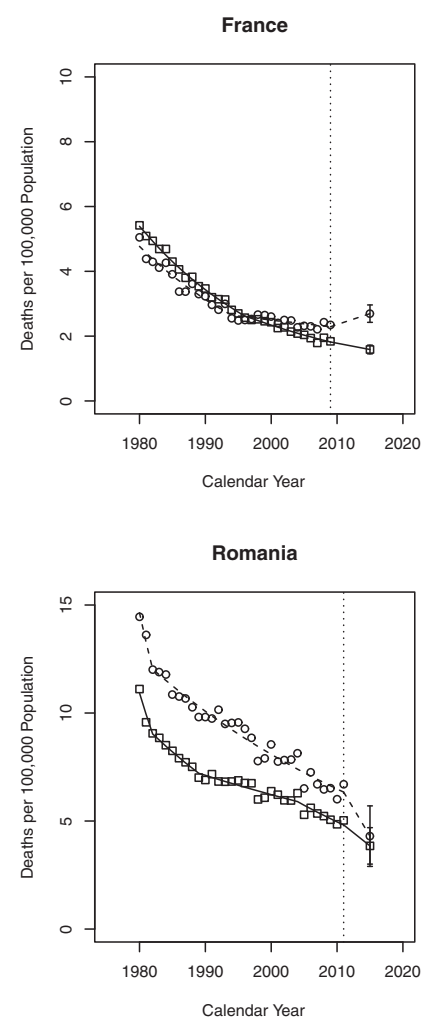

Russian Federation

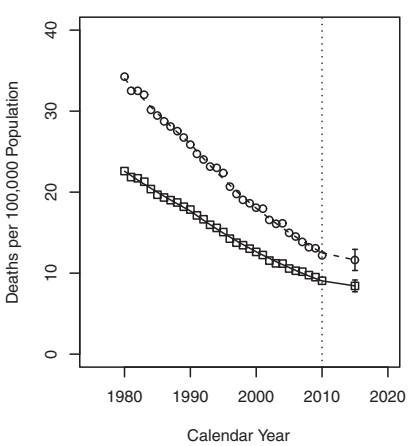

Germany

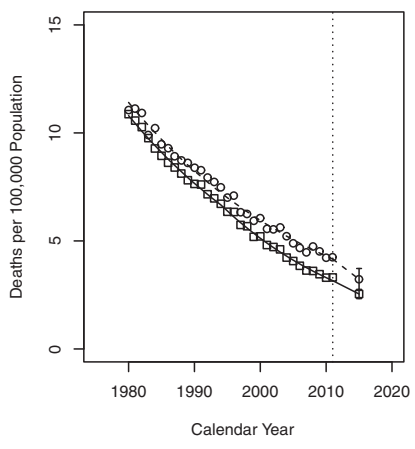

Spain

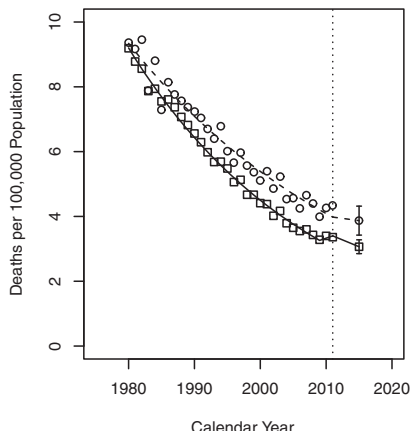

Ukraine

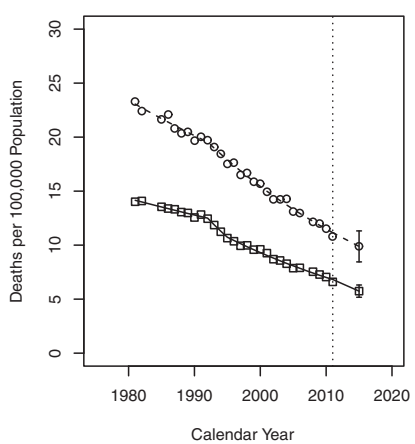

Italy

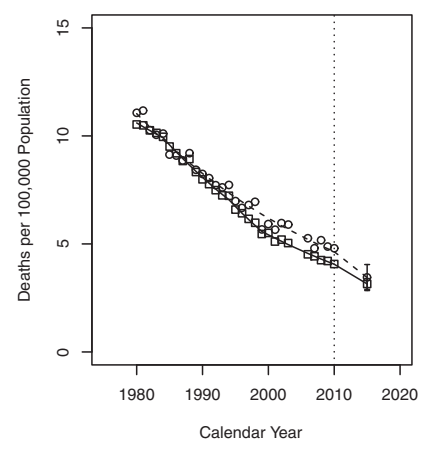

UK
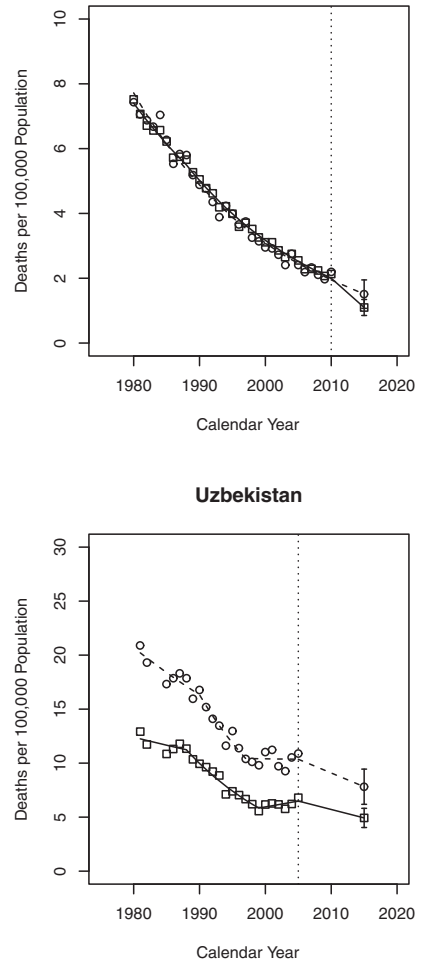

Poland

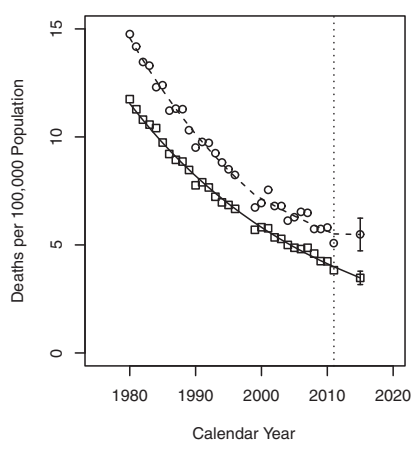

EU
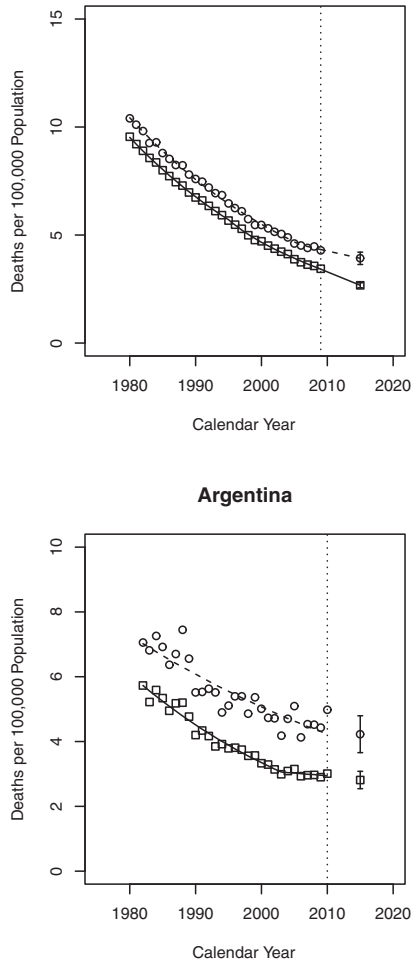

Fig. 3. Joinpoint analysis for gastric cancer mortality in selected European countries, in the European Union, and in other world countries, at all ages $(\square)$ and truncated at 35-64years $(\bigcirc)$ for women, 1980-2011 (when available) and predictions for 2015 (with the corresponding $95 \%$ confidence interval).

men and $-3.4 \%$ in women, in the absence of substantial differences across the major European countries. Likewise, over the last two decades, the EAPC was around $-3.0 \%$ in Russia and Ukraine in both sexes. The recent negative EAPCs in gastric mortality were even larger in Japan and Korea, for both sexes, while they were around $-2.0 \%$ in the USA and most Latin American countries, despite the substantial variation of rates across those countries. However, in the USA, EU and several other major countries worldwide, the EAPCs were smaller than in previous calendar periods.
Tables 1 and 2 give the age-standardised mortality rates from gastric cancer per 100,000 men and women, respectively, in various countries worldwide in 2000 2004 and 2005-2009, and the corresponding percent changes. Gastric cancer mortality fell in most countries, with similar relative declines for both all ages and the truncated (35-64 years) age groups. The relative declines were above $20 \%$ in a few Northern and Central European countries, Costa Rica, Singapore and the Republic of Korea (for both sexes), in Puerto Rico, Australia and New Zealand (for men), and in Mauritius and Hong Kong (for women). Only in Denmark and in few 

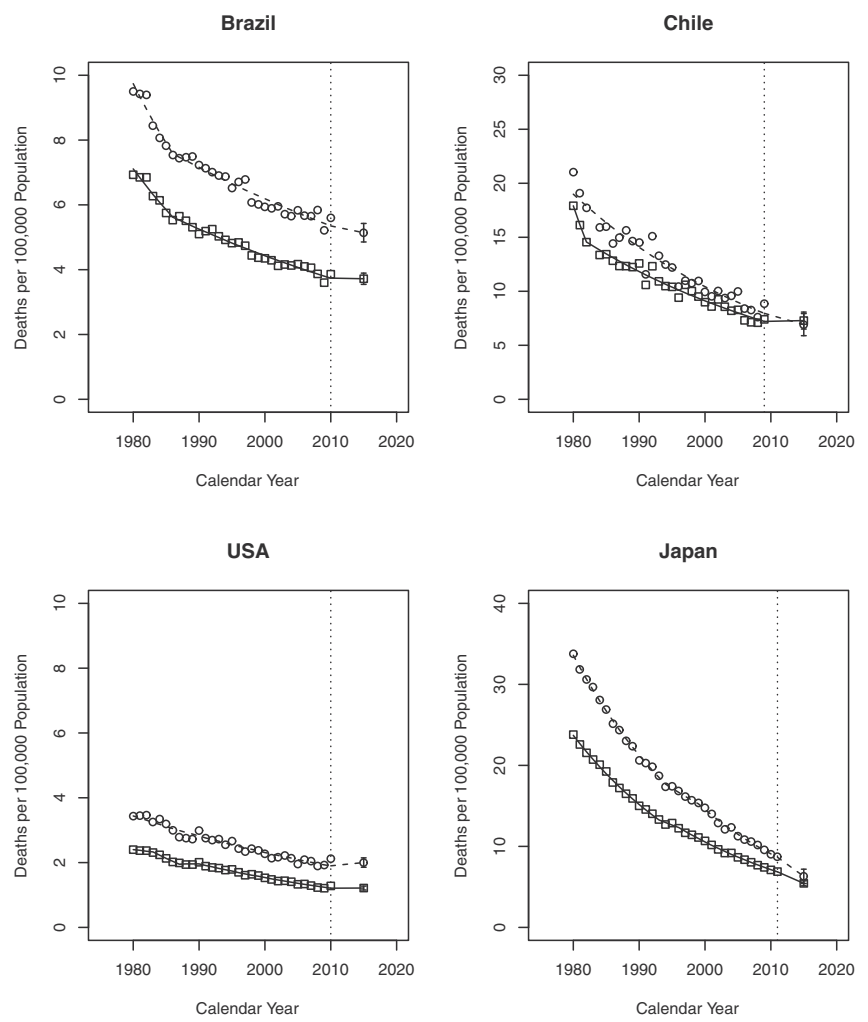
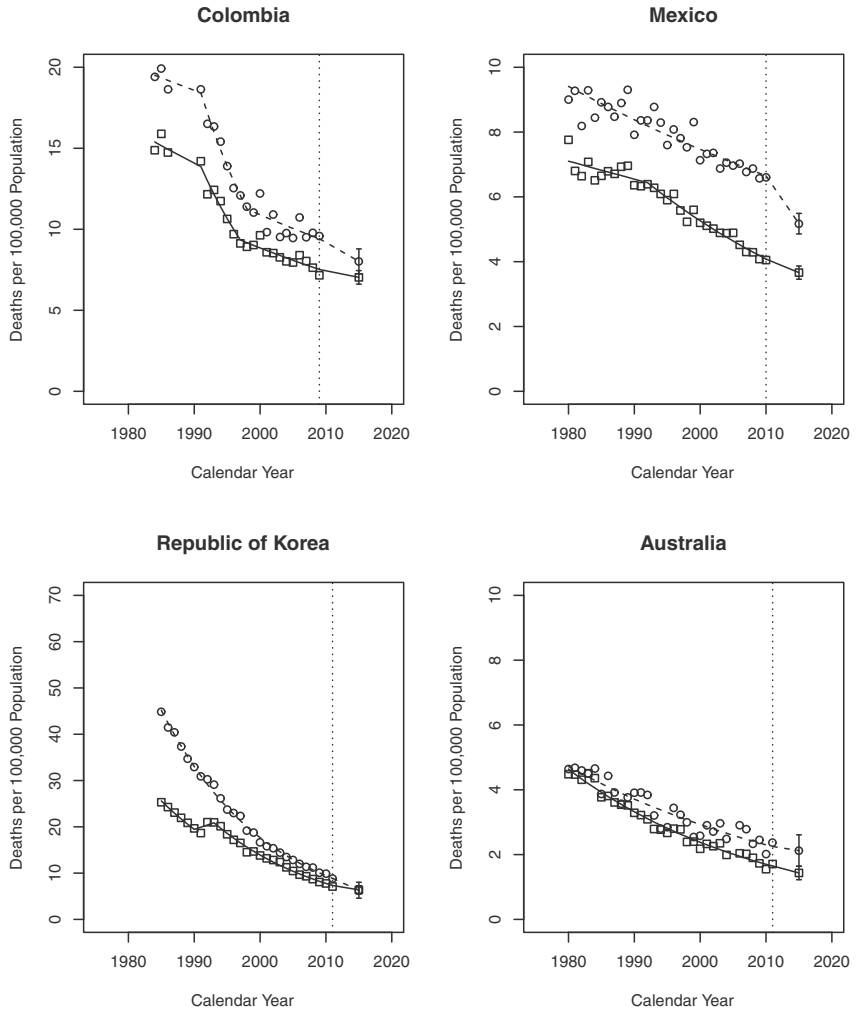

Fig 3. (continued)

countries of the former Soviet Union, gastric cancer mortality did not decrease in both sexes. In 2005-2009, the highest overall rates $(/ 100,000)$ among men were in the Republic of Korea (25.3), the Russian Federation (24.6), Kazakhstan (24.0), Belarus (23.6), Chile (23.1) and Japan (21.0), whereas the lowest ones were in the USA (2.6), Canada (3.6) and Australia (3.8). For the EU as a whole, the rate was $8.0 / 100,000$ men. In women, the highest rates $(/ 100,000)$ were observed in Ecuador (10.5), the Russian Federation (10.1) and the Republic of Korea (9.2), whereas the lowest ones were in the USA (1.3), Canada (1.7) and France (1.9). In EU women, the overall gastric cancer mortality rate was $3.7 / 100,000$.

\subsection{Short-term predictions of mortality rates}

Persisting favourable trends in overall male and female gastric cancer mortality rates are predicted up to 2015 (Figs. 2 and 3, respectively, and Supplementary Table 2A and B). However, a levelling off in the falls is expected in the USA, and a few other countries, particularly at middle-age. In men, the 2015 predicted agestandardised gastric mortality rate/100,000 (number of deaths $)$ is $6.2(\approx 33,900)$ in the EU, $4.4(\approx 2900)$ in France, $5.2(\approx 5400)$ in Germany, $5.8(\approx 5000)$ in Italy, $21.1(\approx 18,100)$ in Russia and $6.9(\approx 3600)$ in Spain. Outside Europe, predicted rates/100,000 (number of deaths) in men are $6.8(\approx 1800)$ in Argentina, $8.8(\approx 9500)$ in
Brazil, $5.7(\approx 3300)$ in Mexico, $2.3(\approx 6400)$ in the USA, $16.1(\approx 32,500)$ in Japan and $17.6(\approx 6800)$ in Korea (Supplementary Table 2A). Corresponding values for women are $2.7(\approx 20,200)$ in the EU, $1.6(\approx 1400)$ in France, $2.5(\approx 3500)$ in Germany, $3.2(\approx 3700)$ in Italy, $8.4(\approx 13,800)$ in Russia and $3.1(\approx 2100)$ in Spain. Predicted rates for women are $2.8(\approx 1000)$ in Argentina, $3.7(\approx 5100)$ in Brazil, $3.7(\approx 2700)$ in Mexico, 1.2 $(\approx 4100)$ in the USA, $5.4(\approx 16,200)$ in Japan and 6.4 $(\approx 3500)$ in Korea (Supplementary Table 2B).

\subsection{Distribution of gastric cardia and non-cardia cases}

Figs. 4 and 5 give the proportion of cardia and noncardia gastric cancers in men and women, respectively, for selected countries from Europe (A) and other world regions (B). For men, among European countries, the proportion of cardia ranged between $11.6 \%$ (Belarus) and $72.0 \%$ (Finland), being higher in Northern and Central Europe and lower in Southern and Eastern Europe (Fig. 4A and Supplementary Table 3). Among other countries worldwide (Fig. 4B and Supplementary Table 3), the highest proportion of cardia cancers was observed in countries with low mortality rates, while those with high rates had the lowest proportion of cardia cancers. The proportion of cardia ranged between $5.8 \%$ (Republic of Korea) and $64.8 \%$ (Iran). For women, we observed a similar geographic pattern, even 
Table 1

Age-standardised (world population) mortality rates from gastric cancer per 100,000 men (at all ages and truncated at 35-64 years) in selected European countries, in the European Union, and in other selected areas of the world in the periods 2000-2004 and 2005-2009 (unless otherwise mentioned in parenthesis), and corresponding percent changes.

\begin{tabular}{|c|c|c|c|c|c|c|}
\hline \multirow[t]{2}{*}{ Country } & \multicolumn{3}{|l|}{ All ages } & \multicolumn{3}{|l|}{$35-64$ years } \\
\hline & $2000-2004$ & 2005-2009 & $\%$ Change & $2000-2004$ & 2005-2009 & $\%$ Change \\
\hline \multicolumn{7}{|l|}{ Europe } \\
\hline Armenia (2000-03/2008-09) & 14.28 & 16.54 & 16 & 20.74 & 22.40 & 8 \\
\hline Austria & 8.72 & 6.64 & -24 & 8.63 & 7.10 & -18 \\
\hline Azerbaijan (2007) & 21.27 & 10.67 & -50 & 30.42 & 13.77 & -55 \\
\hline Belarus (2000-03/2007-09) & 29.19 & 23.62 & -19 & 44.90 & 35.81 & -20 \\
\hline Belgium (2003-04) & 5.30 & 4.65 & -12 & 6.32 & 5.16 & -18 \\
\hline Bulgaria & 13.90 & 12.97 & -7 & 19.95 & 18.58 & -7 \\
\hline Croatia & 17.38 & 14.05 & -19 & 20.13 & 16.74 & -17 \\
\hline Czech Republic & 10.89 & 8.46 & -22 & 11.79 & 10.30 & -13 \\
\hline Denmark & 4.85 & 4.91 & 1 & 6.18 & 6.38 & 3 \\
\hline Estonia & 20.63 & 17.93 & -13 & 28.32 & 24.53 & -13 \\
\hline Finland & 6.92 & 5.80 & -16 & 7.79 & 7.38 & -5 \\
\hline France & 5.87 & 5.11 & -13 & 6.94 & 6.41 & -8 \\
\hline Georgia (2000-01, 2004/2005-07, 2009) & 11.06 & 7.25 & -34 & 14.32 & 9.65 & -33 \\
\hline Germany & 8.69 & 6.95 & -20 & 9.72 & 8.28 & -15 \\
\hline Greece & 7.92 & 6.86 & -13 & 9.40 & 8.25 & -12 \\
\hline Hungary & 15.74 & 12.60 & -20 & 19.31 & 16.52 & -14 \\
\hline Iceland & 7.52 & 5.05 & -33 & 6.21 & 6.74 & 9 \\
\hline Ireland & 7.46 & 6.78 & -9 & 8.03 & 6.81 & -15 \\
\hline Italy (2000-03/2006-09) & 10.89 & 8.89 & -18 & 11.59 & 9.36 & -19 \\
\hline Kazakhstan & 26.71 & 24.02 & -10 & 40.26 & 36.44 & -9 \\
\hline Kyrgyzstan (2005-08) & 22.52 & 23.33 & 4 & 39.68 & 39.51 & -0 \\
\hline Latvia & 20.34 & 19.10 & -6 & 29.61 & 26.11 & -12 \\
\hline Lithuania & 20.96 & 19.04 & -9 & 29.19 & 27.20 & -7 \\
\hline Luxembourg & 6.86 & 5.25 & -23 & 7.65 & 5.24 & -32 \\
\hline Macedonia & 18.26 & 16.08 & -12 & 24.81 & 21.50 & -13 \\
\hline Malta & 7.95 & 7.48 & -6 & 7.07 & 6.00 & -15 \\
\hline Netherlands & 7.38 & 5.95 & -19 & 7.57 & 5.90 & -22 \\
\hline Norway & 6.45 & 4.55 & -29 & 6.21 & 4.94 & -20 \\
\hline Poland & 15.20 & 12.94 & -15 & 19.58 & 16.39 & -16 \\
\hline Portugal & 16.89 & 14.72 & -13 & 22.53 & 20.38 & -10 \\
\hline Republic of Moldova & 16.67 & 16.24 & -3 & 30.01 & 27.06 & -10 \\
\hline Romania & 16.55 & 14.68 & -11 & 24.67 & 21.14 & -14 \\
\hline Russian Federation & 28.73 & 24.60 & -14 & 44.09 & 35.90 & -19 \\
\hline Slovakia & 14.39 & 11.70 & -19 & 18.29 & 13.77 & -25 \\
\hline Slovenia & 15.29 & 12.78 & -16 & 16.61 & 14.15 & -15 \\
\hline Spain & 9.69 & 8.16 & -16 & 12.08 & 10.21 & -15 \\
\hline Sweden & 5.17 & 4.29 & -17 & 5.35 & 4.56 & -15 \\
\hline Switzerland & 5.11 & 4.22 & -17 & 6.10 & 5.04 & -17 \\
\hline Ukraine $(2005-06,2008-09)$ & 22.57 & 19.38 & -14 & 38.38 & 32.66 & -15 \\
\hline United Kingdom & 6.86 & 5.26 & -23 & 6.39 & 4.74 & -26 \\
\hline Uzbekistan (2005) & 11.89 & 12.54 & 5 & 18.94 & 18.23 & -4 \\
\hline European Union (27) & 9.62 & 8.00 & -17 & 11.41 & 9.65 & -15 \\
\hline \multicolumn{7}{|l|}{ America } \\
\hline Argentina & 9.17 & 8.25 & -10 & 11.98 & 11.42 & -5 \\
\hline Brazil & 11.06 & 10.17 & -8 & 14.79 & 13.47 & -9 \\
\hline Chile & 27.42 & 23.09 & -16 & 29.57 & 24.92 & -16 \\
\hline Colombia & 17.56 & 16.67 & -5 & 20.33 & 18.99 & -7 \\
\hline Costa Rica & 23.25 & 17.22 & -26 & 26.63 & 17.38 & -35 \\
\hline Cuba & 5.99 & 5.93 & -1 & 7.90 & 7.78 & -2 \\
\hline Ecuador & 16.62 & 15.48 & -7 & 17.94 & 17.05 & -5 \\
\hline Mexico & 7.70 & 6.45 & -16 & 9.33 & 8.32 & -11 \\
\hline Puerto Rico (2000-03/2005-07) & 5.96 & 4.73 & -21 & 7.11 & 4.80 & -32 \\
\hline Uruguay (2000-01, 2003-04/) & 11.44 & 10.42 & -9 & 15.29 & 14.21 & -7 \\
\hline Venezuela (2005-07) & 11.77 & 11.37 & -3 & 14.25 & 13.86 & -3 \\
\hline Canada & 4.13 & 3.59 & -13 & 5.38 & 4.84 & -10 \\
\hline United States of America (USA) & 3.00 & 2.55 & -15 & 4.37 & 3.78 & -14 \\
\hline
\end{tabular}


Table 1 (continued)

\begin{tabular}{|c|c|c|c|c|c|c|}
\hline \multirow[t]{2}{*}{ Country } & \multicolumn{3}{|l|}{ All ages } & \multicolumn{3}{|l|}{$35-64$ years } \\
\hline & 2000-2004 & 2005-2009 & $\%$ Change & 2000-2004 & 2005-2009 & $\%$ Change \\
\hline \multicolumn{7}{|l|}{ Africa, Asia, Oceania } \\
\hline Mauritius (2005-08) & 9.83 & 9.48 & -4 & 12.37 & 12.55 & 1 \\
\hline Hong Kong SAR & 8.32 & 6.80 & -18 & 9.91 & 7.73 & -22 \\
\hline Israel & 7.20 & 6.21 & -14 & 8.05 & 7.08 & -12 \\
\hline Japan & 24.59 & 20.98 & -15 & 26.75 & 22.09 & -17 \\
\hline Republic of Korea & 34.21 & 25.27 & -26 & 40.14 & 28.09 & -30 \\
\hline Singapore & 11.03 & 8.84 & -20 & 9.03 & 6.57 & -27 \\
\hline Australia (2006-09) & 4.72 & 3.76 & -20 & 5.02 & 4.31 & -14 \\
\hline New Zealand & 6.68 & 4.94 & -26 & 8.04 & 5.84 & -27 \\
\hline
\end{tabular}

Table 2

Age-standardised (world population) mortality rates from gastric cancer per 100,000 women (at all ages and truncated at 35-64 years) in selected European countries, in the European Union, and in other selected areas of the world in the periods 2000-2004 and 2005-2009 (unless otherwise mentioned in parenthesis), and corresponding percent changes.

\begin{tabular}{|c|c|c|c|c|c|c|}
\hline \multirow[t]{2}{*}{ Country } & \multicolumn{3}{|l|}{ All ages } & \multicolumn{3}{|c|}{ Age $35-64$ years } \\
\hline & $2000-2004$ & 2005-2009 & $\%$ Change & 2000-2004 & 2005-2009 & $\%$ Change \\
\hline \multicolumn{7}{|l|}{ Europe } \\
\hline Armenia (2000-03/2008-09) & 6.35 & 6.84 & 8 & 9.50 & 7.57 & -20 \\
\hline Austria & 4.75 & 3.65 & -23 & 5.16 & 4.20 & -19 \\
\hline Azerbaijan (2007) & 10.13 & 5.07 & -50 & 13.77 & 6.34 & -54 \\
\hline Belarus $(2000-03 / 2007-09)$ & 11.50 & 8.96 & -22 & 16.88 & 12.91 & -24 \\
\hline Belgium (2003-04) & 2.24 & 2.03 & -9 & 2.42 & 2.53 & 5 \\
\hline Bulgaria & 6.62 & 5.85 & -12 & 8.53 & 7.48 & -12 \\
\hline Croatia & 6.99 & 5.71 & -18 & 8.20 & 6.66 & -19 \\
\hline Czech Republic & 5.32 & 4.22 & -21 & 6.22 & 5.34 & -14 \\
\hline Denmark & 2.35 & 2.49 & 6 & 3.02 & 3.27 & 8 \\
\hline Estonia & 9.49 & 8.37 & -12 & 13.73 & 10.98 & -20 \\
\hline Finland & 3.79 & 3.28 & -13 & 4.57 & 4.51 & -1 \\
\hline France & 2.23 & 1.91 & -14 & 2.45 & 2.32 & -5 \\
\hline Georgia (2000-01, 2004/2005-07, 2009) & 5.38 & 3.27 & -39 & 7.02 & 4.64 & -34 \\
\hline Germany & 4.71 & 3.72 & -21 & 5.60 & 4.67 & -17 \\
\hline Greece & 3.82 & 3.30 & -14 & 4.24 & 3.85 & -9 \\
\hline Hungary & 6.78 & 5.70 & -16 & 8.21 & 7.74 & -6 \\
\hline Iceland & 2.84 & 2.89 & 2 & 2.12 & 2.23 & 5 \\
\hline Ireland & 3.69 & 3.29 & -11 & 3.96 & 3.42 & -14 \\
\hline Italy (2000-03/2006-09) & 5.21 & 4.35 & -17 & 5.86 & 5.03 & -14 \\
\hline Kazakhstan & 11.59 & 9.20 & -21 & 17.56 & 12.93 & -26 \\
\hline Kyrgyzstan (2005-08) & 9.03 & 8.72 & -3 & 14.11 & 13.26 & -6 \\
\hline Latvia & 8.82 & 7.74 & -12 & 12.14 & 10.89 & -10 \\
\hline Lithuania & 8.73 & 7.25 & -17 & 11.83 & 10.31 & -13 \\
\hline Luxembourg & 2.46 & 2.63 & 7 & 1.43 & 3.92 & 174 \\
\hline Macedonia & 8.16 & 7.25 & -11 & 10.08 & 9.79 & -3 \\
\hline Malta & 4.11 & 2.78 & -32 & 4.67 & 3.55 & -24 \\
\hline Netherlands & 3.44 & 2.92 & -15 & 4.11 & 3.48 & -15 \\
\hline Norway & 3.07 & 2.77 & -10 & 3.24 & 3.21 & -1 \\
\hline Poland & 5.44 & 4.68 & -14 & 6.84 & 6.15 & -10 \\
\hline Portugal & 7.78 & 6.67 & -14 & 10.11 & 8.78 & -13 \\
\hline Republic of Moldova & 6.91 & 7.13 & 3 & 11.66 & 11.97 & 3 \\
\hline Romania & 6.16 & 5.31 & -14 & 8.03 & 6.68 & -17 \\
\hline Russian Federation & 11.75 & 10.06 & -14 & 16.98 & 13.91 & -18 \\
\hline Slovakia & 5.76 & 5.05 & -12 & 6.85 & 6.48 & -5 \\
\hline Slovenia & 6.11 & 5.12 & -16 & 6.23 & 5.82 & -7 \\
\hline Spain & 4.15 & 3.50 & -16 & 5.02 & 4.37 & -13 \\
\hline Sweden & 2.85 & 2.17 & -24 & 3.49 & 2.65 & -24 \\
\hline Switzerland & 2.25 & 2.05 & -9 & 2.76 & 2.66 & -4 \\
\hline Ukraine $(2005-06,2008-09)$ & 8.88 & 7.65 & -14 & 14.70 & 12.57 & -14 \\
\hline United Kingdom & 2.89 & 2.29 & -21 & 2.75 & 2.20 & -20 \\
\hline Uzbekistan (2005) & 6.13 & 6.80 & 11 & 10.36 & 10.90 & 5 \\
\hline European Union (27) & 4.39 & 3.65 & -17 & 5.17 & 4.46 & -14 \\
\hline
\end{tabular}


Table 2 (continued)

\begin{tabular}{|c|c|c|c|c|c|c|}
\hline \multirow[t]{2}{*}{ Country } & \multicolumn{3}{|l|}{ All ages } & \multicolumn{3}{|c|}{ Age $35-64$ years } \\
\hline & $2000-2004$ & 2005-2009 & $\%$ Change & 2000-2004 & 2005-2009 & $\%$ Change \\
\hline \multicolumn{7}{|l|}{ America } \\
\hline Argentina & 3.46 & 3.24 & -6 & 4.66 & 4.54 & -3 \\
\hline Brazil & 4.59 & 4.32 & -6 & 5.82 & 5.64 & -3 \\
\hline Chile & 9.76 & 8.33 & -15 & 9.68 & 8.60 & -11 \\
\hline Colombia & 9.39 & 8.55 & -9 & 10.40 & 9.80 & -6 \\
\hline Costa Rica & 11.41 & 8.49 & -26 & 12.15 & 9.96 & -18 \\
\hline Cuba & 3.28 & 3.06 & -7 & 4.32 & 3.72 & -14 \\
\hline Ecuador & 11.49 & 10.53 & -8 & 13.59 & 12.25 & -10 \\
\hline Mexico & 5.49 & 4.78 & -13 & 7.15 & 6.83 & -4 \\
\hline Puerto Rico (2000-03/2005-07) & 2.85 & 2.38 & -16 & 3.27 & 2.88 & -12 \\
\hline Uruguay (2000-01, 2003-04/) & 4.62 & 4.12 & -11 & 6.63 & 5.21 & -21 \\
\hline Venezuela $(2005-07)$ & 6.95 & 5.93 & -15 & 7.97 & 7.11 & -11 \\
\hline Canada & 1.92 & 1.68 & -13 & 2.70 & 2.45 & -9 \\
\hline United States of America (USA) & 1.46 & 1.28 & -12 & 2.19 & 1.99 & -9 \\
\hline \multicolumn{7}{|l|}{ Africa, Asia, Oceania } \\
\hline Mauritius (2005-08) & 5.39 & 4.19 & -22 & 7.04 & 6.27 & -11 \\
\hline Hong Kong SAR & 4.45 & 3.35 & -25 & 6.14 & 4.37 & -29 \\
\hline Israel & 3.73 & 3.43 & -8 & 4.69 & 4.60 & -2 \\
\hline Japan & 9.76 & 8.02 & -18 & 13.22 & 10.49 & -21 \\
\hline Republic of Korea & 12.66 & 9.21 & -27 & 15.12 & 11.48 & -24 \\
\hline Singapore & 6.04 & 4.77 & -21 & 6.31 & 4.91 & -22 \\
\hline Australia (2006-09) & 2.22 & 1.92 & -14 & 2.73 & 2.61 & -4 \\
\hline New Zealand & 3.06 & 2.77 & -9 & 3.85 & 4.26 & 11 \\
\hline
\end{tabular}

though the total number of cases and the proportion of cardia cancers were lower. The proportion ranged between 10.6\% (Italy) and 44.5\% (United Kingdom), among large European countries (Fig. 5A and Supplementary Table 4), and from 4.3\% (Republic of Korea) to $31.5 \%$ (Australia), among other countries worldwide (Fig. 5B and Supplementary Table 4).

\section{Discussion}

This updated analysis of worldwide gastric cancer mortality patterns and trends confirms that mortality rates continued to decrease in most countries worldwide over the last few years, although there still is a substantial variation (up to 10 -fold) in rates across countries, and in some of them the declines are smaller - not only in absolute, but also in proportional terms - than in the past.

These analyses are based on data from the WHO database [12] and rely on the completeness and quality of the data provided by each country. Death certification from gastric cancer is sufficiently reliable and valid to permit inference on trends in most countries considered, especially at age 35-64 years. However, there are some differences in the coverage of death certification, particularly in some countries from the former Soviet Union and from Latin America, and no data are available from most African and Asian countries, thus precluding a more comprehensive picture of gastric mortality trends.
The mortality trends reflect the differences in exposure to the main risk factors for gastric cancer $[4,23$ 25] across populations, age-groups, and cohorts of birth over different time periods [26].

Helicobacter pylori infection is the key determinant of gastric cancer and possibly a necessary cause [4]. In the late 1980s/early 1990s the prevalence of H. Pylori was below $20 \%$ among young adults in the USA [27] and in several high-income countries particularly from Western and Northern Europe [28,29], whereas in Portugal [5], Latvia [30] or Chile [31] the prevalence was two to fourfold higher in the late 1990s/early 2000s. In the Republic of Korea [32,33] and Japan [34] - currently presenting some of the highest gastric cancer mortality - the prevalence of $H$. pylori was high in the early 1990s, although most recent data show lower prevalence estimates. Since $H$. pylori infection is acquired mainly during childhood, this most likely reflects the replacement of the older generations that had been infected in their early lives, by younger subjects with a lower risk of infection $[33,35]$. The distinct patterns in the prevalence of $H$. pylori infection may explain the fact that - despite the similar economic development in the USA, the EU and Japan - there are major differences in the burden of gastric cancer across these countries; if the observed trends remain the same in the future, it would take at least three decades for Japan and two decades for the EU to reach recent US rates. 
The decline in gastric cancer has become gradually smaller in some countries, particularly the USA. In France, mortality rates are predicted not to further decrease over the next years in the middle-aged population, in agreement with a less favourable tendency in most recent cohorts [26]. This is probably explained by the fact that a low and stable prevalence of $H$. pylori infection has been achieved in these countries long time ago.
Tobacco consumption - which also accounts for a sizable proportion of gastric cancer cases [36] - has been long declining in men from most of the countries with the lowest gastric cancer mortality [37], while trends in smoking have been less favourable in Southern or Eastern Europe $[37,38]$. In Japan, smoking prevalence has been high among men, particularly among those born before the late 1950s [39].

A

Proportion of Cardia and Non-cardia cases in Men
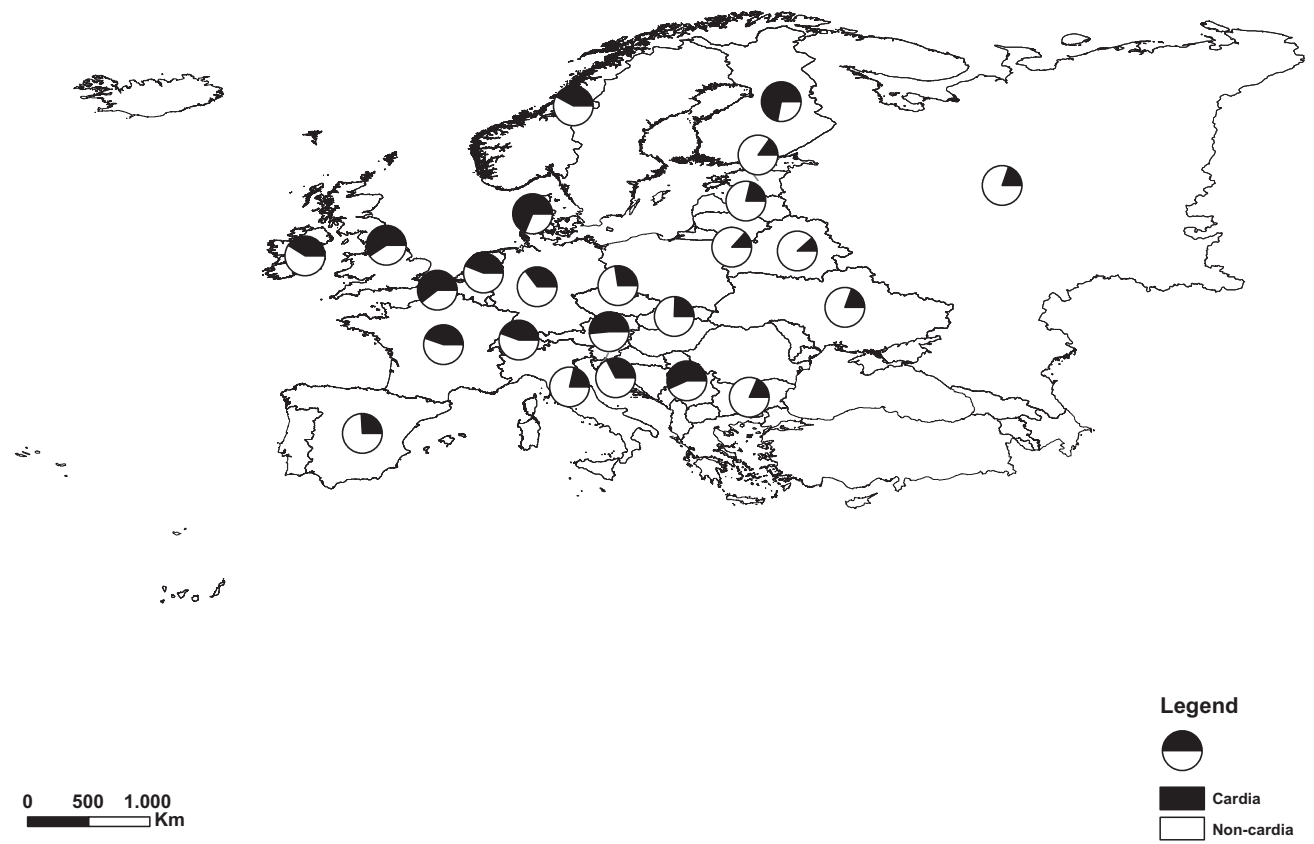

B Proportion of Cardia and Non Cardia cases in Men

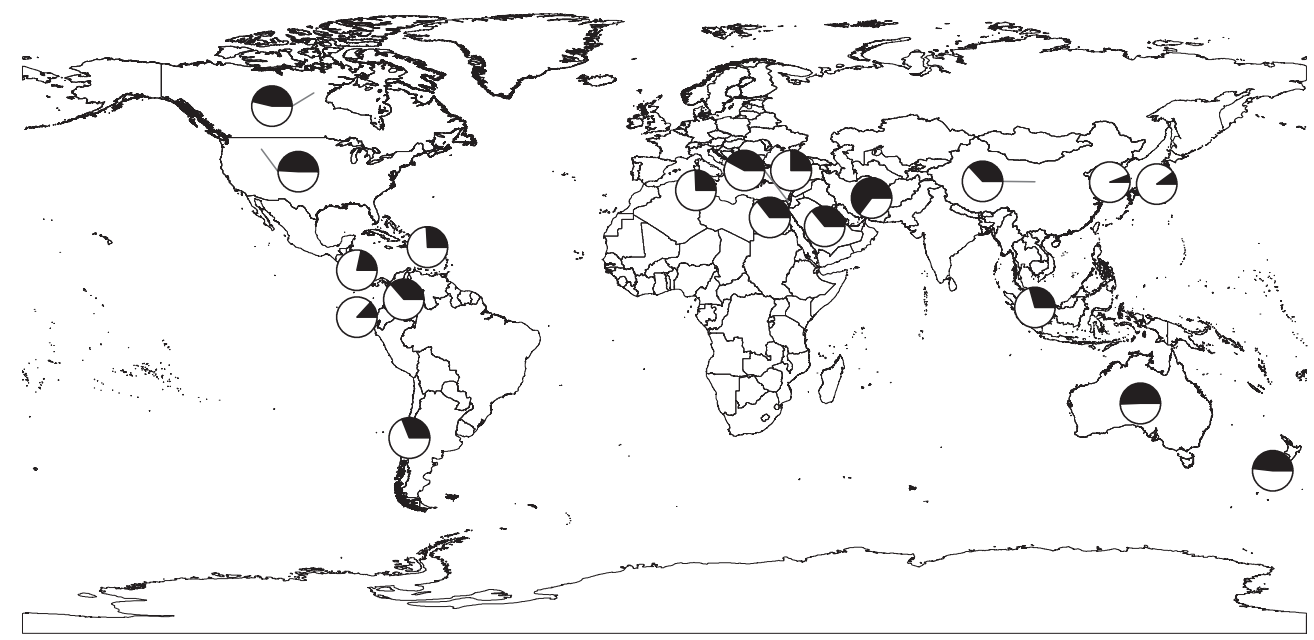


According to Soerjomataram et al. [40], if southern and eastern European countries with higher stomach cancer rates (Portugal, Estonia and Lithuania) presented the same patterns for H. pylori and smoking prevalence as northern countries (Denmark, Sweden), more than $50 \%$ of the stomach cancer cases observed in $2002(\approx 48,000)$ would be avoidable [40].

The eradication of $H$. pylori infection is an important preventive and therapeutic measure for mucosa-associated lymphoid tissue (MALT) lymphoma, which accounts for about $50 \%$ of gastric lymphomas [41], and for which incidence has been decreasing [42]. However, this measure is only recommended for primary prevention of gastric cancer in high risk areas and high risk individuals [43].

The gradual improvements in gastric cancer diagnosis - new endoscopy and staging techniques, such as computerised tomography scanning, endoscopic ultrasound - and treatment - introduction of chemoradiotherapy after surgery [44], perioperative chemotherapy [45], new molecularly targeted therapy for both treatment and palliative care [46] and centralisation of surgical care [47] - may have had some role in the observed trends. However, gastric cancer survival has remained unsatisfactorily low in most areas of the world [48]. This may reflect, at least partially, the outweighing of the impact of these advances in disease management by the increasing contribution of gastric cancer cases located in the cardia $[49,50]$ and with diffuse histological type [51,52], which present worse prognosis [53]. Screening programs have been implemented in Korea [54] and Japan [55], but these cannot explain the decrease observed in other world regions.

In relation to gastric cancer incidence, there is a wide variation in the relative contribution of cardia and noncardia cancers to the overall number of cases, with a generally higher proportion of the former among countries with higher gastric cancer rates. This is in accordance with the levelling off of mortality rates in several high-income countries, and suggests that cardia cancer would be responsible for an increasingly higher gastric cancer burden in the future. However, our results by gastric cancer subtypes must be interpreted with caution since, in some countries, incidence data had only a regional coverage, and because, in most cancer registries, a large proportion of gastric cancer cases had unknown or unspecified topography. Although in our analysis this limitation was partially overcome by selecting only the countries with a larger number of classified cases, it shows the importance of improving the monitoring of gastric cancer incidence.

In conclusion, despite the global downward trends in gastric cancer mortality, further declines in gastric cancer mortality rates may require more intensive efforts for the prevention and control of $H$. pylori infection [43] and other risk factors, including tobacco and diet [56], as well as exposures associated with cancer of the cardia, such as reflux disease [57] and obesity [58], which have been increasing in Central and Northern Europe [59] and in North America [8]. Moreover, there is still the need for intervention to improve early diagnosis and management in high risk countries, some of which are now high-income settings. Prevention of cardia cancers has become a priority in several regions.

\section{Role of the funding sources}

The funding sources had no role in study design, in the collection, analysis and interpretation of data, in the writing of the report or in the decision to submit the paper for publication.

Fig. 4. Proportion of cardia and non-cardia gastric cancers in men. A - Selected European countries, B - Other world countries. Data refer to registries or groups of registries from the same country, with data available in Cancer Incidence in Five Continents (CI5)-X, with at least 20\% of the cases with topography defined as cardia (C16.0) or non-cardia (C16.1-6: Fundus, Body, Pyloric, Pyloric, Lesser and Greater Curvature), and a minimum of 100 cases in these topography groups (A) Austria, Belarus, Belgium, Bulgaria, Czech Republic, Denmark, Estonia, Finland, France: Bas-Rhin, Calvados, Doubs, Haut-Rhin, Herault, Isere, Loire Atlantique, Manche, Somme, Tarn, Vendee; Germany: Brandenburg, Bremen, Free State of Saxony, Hamburg, Mecklenburg-Western Pomerania, Munich, North-Rhine-Westphalia, Saarland, Schleswig-Holstein; Ireland; Italy: Alto Adige, Biella Province, Brescia Province, Catania-Messina, Catanzaro, Ferrara Province, Florence and Prato Provinces, Friuli-Venezia Giulia, Genova Province, Latina, Lombardy (Como Province, Lecco Province, Milan, Varese Province), Mantova, Modena Province, Naples, Nuoro, Palerme, Parma Province, Ragusa Province, Reggio Emilia Province, Romagna Region, Salerno Province, Sassari Province, Sondrio. South Lombardy, Syracuse Province, Torino, Trapani, Trento, Umbria Region, Veneto Region; Latvia, Lithuania The Netherlands, Norway; Russia, St. Petersburg; Serbia, Central; Slovakia; Slovenia; Spain: Albacete, Asturias, Basque Country, Canary Islands, Ciudade Real, Cuenca, Girona, Granada, La Rioja, Mallorca, Murcia, Navarra, Tarragona; Switzerland: Basel, Geneva, Graubunden and Glarus, Neuchatel, St. GallAppenzell, Ticino, Valais, Vaud, Zurich, Ukraine, United Kingdom (UK): England, Northern Ireland, Scotland, Wales. (B) Egypt, Gharbiah; Tunisia, North; Chile, Biobio Province, Region of Antofagasta, Valdivia; Colombia: Bucaramanga, Cali, Manizales, Pasto; Costa Rica, Ecuador: Cuenca, Quito; Puerto Rico, Canada, United States of America (USA), National Program of Cancer Registries (NPCR); China: Beijing City, Cixian County, Haining County, Hong Kong, Jiashan County, Jiaxing City, Macao, Nangang District, Harbin City, Qidong County, Shangai City, Wuhan City, Yangcheng County, Yanting County, Zhongshan City; Iran, Golestan Province; Israel, Japan: Aichi Prefecture, Fukui Prefecture, Hiroshima, Miyagi Prefecture, Nagasaki Prefecture, Niigata Prefecture, Osaka Prefecture, Saga Prefecture; Republic of Korea, Saudi Arabia, Riyadh: Saudi; Singapore, Turkey: Antalya, Edirne, Izmir, Trabzon; Australia: Australian Capital Territory, New South Wales, Northern Territory, Queensland, Tasmania, Victoria, South Australia, Western Australia; New Zealand. 

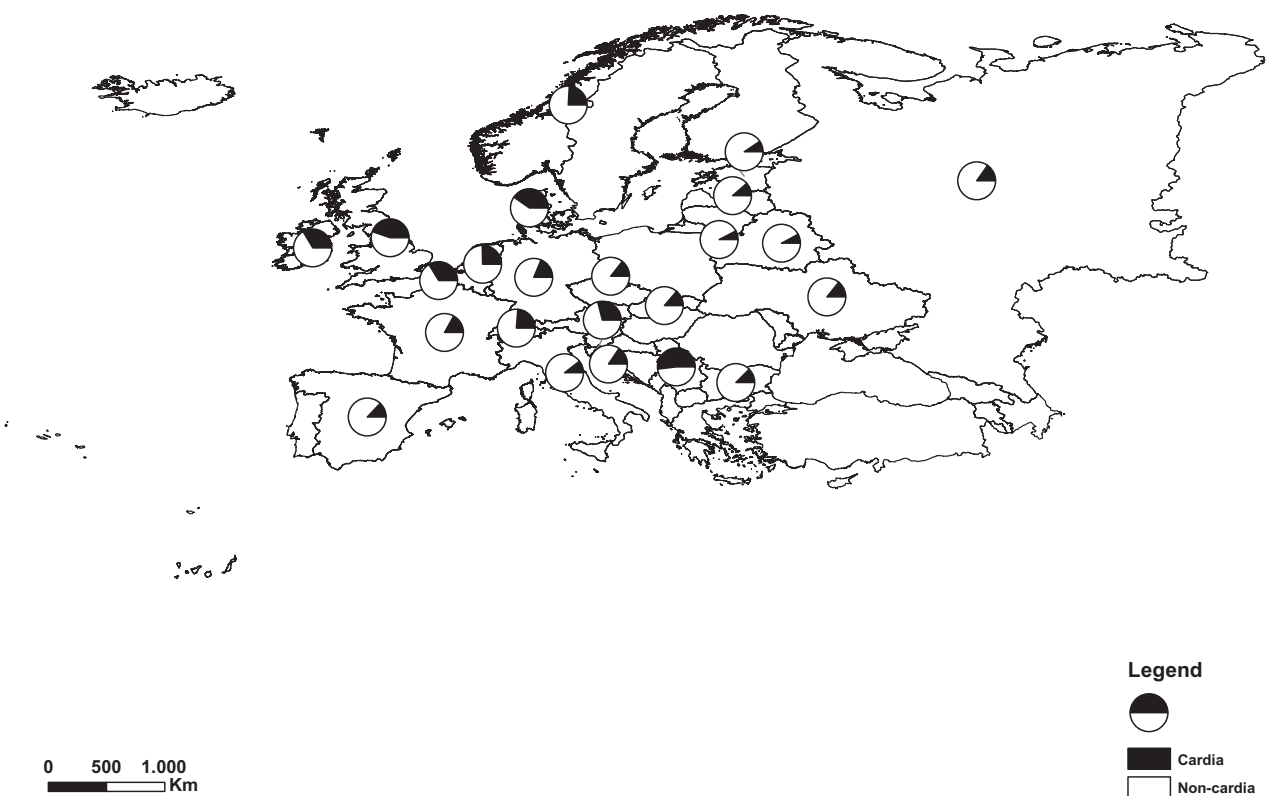

B Proportion of Cardia and Non Cardia cases in Women
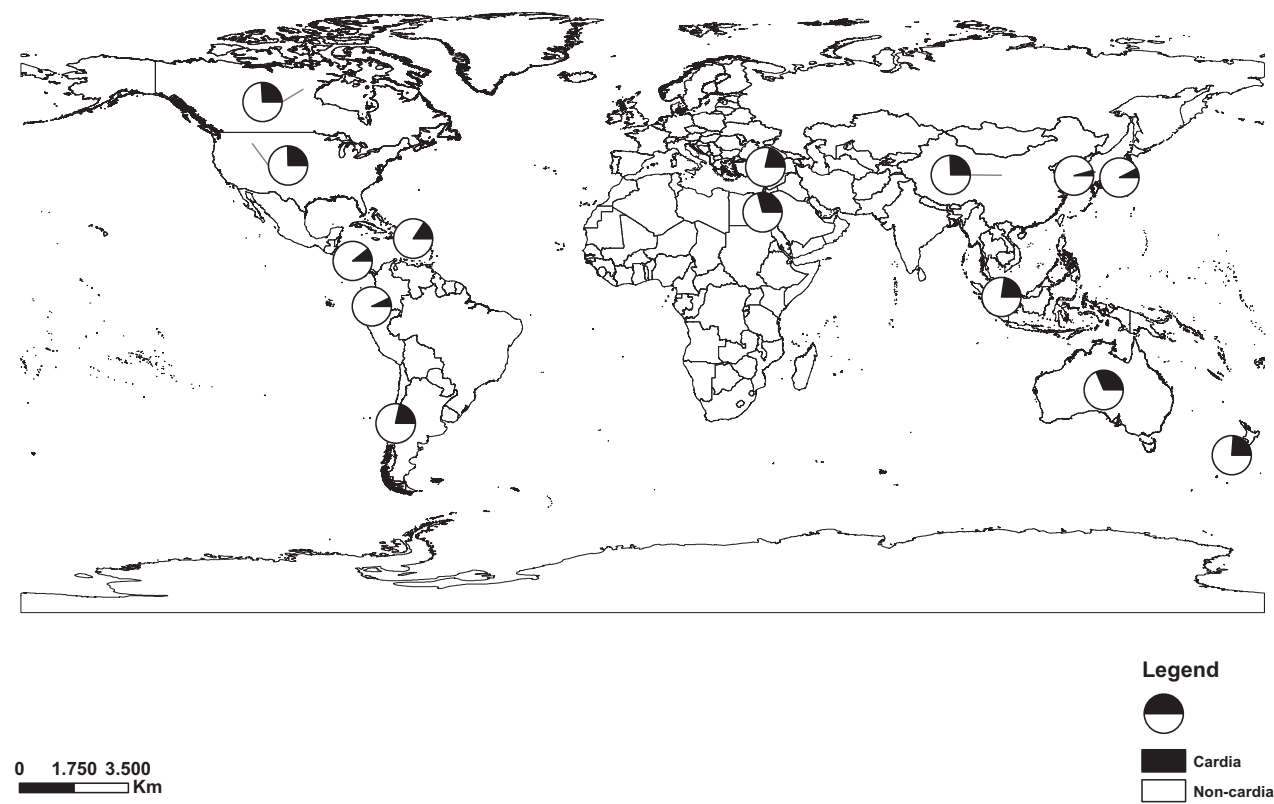

Fig. 5. Proportion of cardia and non-cardia gastric cancers in women. A - Selected European countries, B - Other world countries. Data refer to registries or groups of registries from the same country, with data available in Cancer Incidence in Five Continents (CI5)-X, with at least 20\% of the cases with topography defined as cardia (C16.0) or non-cardia (C16.1-6: Fundus, Body, Pyloric, Pyloric, Lesser and Greater Curvature), and a minimum of 100 cases in these topography groups (A) Austria, Belarus, Belgium, Bulgaria, Czech Repulbic, Denmark, Estonia, France: Bas-Rhin, Calvados, Doubs, Haut-Rhin, Herault, Isere, Loire Atlantique, Manche, Somme, Tarn, Vendee; Germany: Brandenburg, Bremen, Free State of Saxony, Hamburg, Mecklenburh- Western Pomerania, Munich, North-Rhine-Westphalia, Saarland, Schleswig-Holstein; Ireland; Italy: Alto Adige, Biella Province, Brescia Province, Catania-Messina, Catanzaro, Ferrara Province, Florence and Prato Provinces, Friuli-Venezia Giulia, Genova Province, Latina, Lombardy (Como Province, Lecco Province, Milan, Varese Province), Mantova, Modena Province, Naples, Nuoro, Palerme, Parma Province, Ragusa Province, Reggio Emilia Province, Romagna Region, Salerno Province, Sassari Province, Sondrio. South Lombardy, Syracuse Province, Torino, Trapani, Trento, Umbria Region, Veneto Region; Latvia, Lithuania, The Netherlands, Norway, Russia, St. Petersburg; Serbia, Central; Slovakia; Slovenia; Spain: Albacete, Asturias, Basque Country, Canary Islands, Ciudade Real, Cuenca, Girona, Granada, La Rioja, Mallorca, Murcia, Navarra, Tarragona; Switzerland: Basel, Geneva, Graubunden and Glarus, Newchatel, St. Gall-Appenzell, Ticino, Valais, Vaud, Zurich, Ukraine, United Kingdom (UK): England, Northern Ireland, Scotland, Wales. (B) Chile, Biobio Province, Region of Antofagasta, Valdivia; Costa Rica, Ecuador: Cuenca, Quito; Puerto Rico, Canada, United States of America (USA), National Program of Cancer Registries (NPCR); China: Beijing City, Cixian County, Haining County, Hong Kong, Jiashan County, Jiaxing City, Macao, Nangang District, Harbin City, Qidong County, Shangai City, Wuhan City, Yangcheng County, Yanting County, Zhongshan City; Israel, Japan: Aichi Prefecture, Fukui Prefecture, Hiroshima, Miyagi Prefecture, Nagasaki Prefecture, Niigata Prefecture, Osaka Prefecture, Saga Prefecture; Republic of Korea, Singapore, Turkey: Antalya, Edirne, Izmir, Trabzon. Australia: Australian Capital Territory, New South Wales, Northern Territory, Queensland, Tasmania, Victoria, South Australia, Western Australia; New Zealand. 


\section{Conflict of interest statement}

None declared.

\section{Acknowledgements}

This work was supported by 'Fundação para a Ciência e a Tecnologia' (PTDC/SAU-EPI/122460/2010 and SFRH/BPD/75918/2011), the Italian Association for Cancer Research (Grant 10264), and the Swiss League and the Swiss Foundation for Research Against Cancer (Grant 2437-08-2009).

\section{Appendix A. Supplementary data}

Supplementary data associated with this article can be found, in the online version, at http://dx.doi.org/ 10.1016/j.ejca.2014.01.029.

\section{References}

[1] Bertuccio P, Chatenoud L, Levi F, Praud D, Ferlay J, Negri E, et al. Recent patterns in gastric cancer: a global overview. Int J Cancer 2009; 125(3):666-73.

[2] Bosetti C, Bertuccio P, Malvezzi M, Levi F, Chatenoud L, Negri E, et al. Cancer mortality in Europe, 2005-2009, and an overview of trends since 1980. Ann Oncol 2013;24(10):2657-71.

[3] Peleteiro B, Severo M, La Vecchia C, Lunet N. Model-based patterns in stomach cancer mortality worldwide. Eur J Cancer Prev 2013. http://dx.doi.org/10.1097/CEJ.0b013e328364f2b6. [Epub ahead of print].

[4] Peleteiro B, La Vecchia C, Lunet N. The role of Helicobacter pylori infection in the web of gastric cancer causation. Eur J Cancer Prev 2012;21(2):118-25.

[5] Bastos J, Peleteiro B, Barros R, Alves L, Severo M, de Fatima Pina M, et al. Sociodemographic determinants of prevalence and incidence of Helicobacter pylori infection in Portuguese adults. Helicobacter 2013;18(6):413-22.

[6] Forman D, Bray F, Brewster DH, Gombe Mbalawa C, Kohler B, Piñeros M, et al., editors. International Agency for Research on Cancer. Cancer Incidence in Five Continents, Vol. X (electronic version). Lyon: IARC; 2013.

[7] Anderson WF, Camargo MC, Fraumeni Jr JF, Correa P, Rosenberg PS, Rabkin CS. Age-specific trends in incidence of noncardia gastric cancer in US adults. JAMA 2010;303(17):1723-8.

[8] Camargo MC, Anderson WF, King JB, Correa P, Thomas CC, Rosenberg PS, et al. Divergent trends for gastric cancer incidence by anatomical subsite in US adults. Gut 2011;60(12):1644-9.

[9] Steevens J, Botterweck AA, Dirx MJ, van den Brandt PA, Schouten LJ. Trends in incidence of oesophageal and stomach cancer subtypes in Europe. Eur J Gastroenterol Hepatol 2010;22(6):669-78.

[10] Abrams JA, Gonsalves L, Neugut AI. Diverging trends in the incidence of reflux-related and Helicobacter pylori-related gastric cardia cancer. J Clin Gastroenterol 2013;47(4):322-7.

[11] Lindblad M, Ye W, Lindgren A, Lagergren J. Disparities in the classification of esophageal and cardia adenocarcinomas and their influence on reported incidence rates. Ann Surg 2006;243(4):479-85.

[12] WHO mortality database. World Health Organization Statistical Information System, Available from http://www.who.int/ healthinfo/statistics/mortality_rawdata/en/index.html. [Accessed on July 2012].
[13] World Health Organization. International Classification of Disease and related health problems: 8th revision. Geneva: World Health Organization; 1965.

[14] World Health Organization. International Classification of Disease and related health problems: 9th revision. Geneva: World Health Organization; 1977.

[15] World Health Organization. International Classification of Disease and related health problems: 10th revision. Geneva: World Health Organization; 1992.

[16] National Cancer Institute. Joinpoint regression program. Statistical methodology and applications branch and data modeling branch, surveillance research program 3.5; 2011. Available from: http://srabcancergov/joinpoint/.

[17] Clegg LX, Hankey BF, Tiwari R, Feuer EJ, Edwards BK. Estimating average annual per cent change in trend analysis. Stat Med 2009;28(29):3670-82.

[18] Malvezzi M, Bertuccio P, Levi F, La Vecchia C, Negri E. European cancer mortality predictions for the year 2013. Ann Oncol 2013;24(3):792-800.

[19] Faraway JJ. Linear models with R. Taylor \& Francis; 2009.

[20] Eurostat population database. European Commission, Available from: http://epp.eurostat.ec.europa.eu/portal/page/portal/eurostat/home/. [Accessed on October 2012].

[21] World Population Prospects. The 2012 Revision. United Nations Department of Economic and Social Affairs. Available from: http:// esa.un.org/unpd/wpp/unpp/panel_indicators.htm. [Accessed on 3 September 2013].

[22] ESRI. ArcGIS Desktop: release 10. In: Environmental Systems Research Institute, editor. Redlands, CA; 2011.

[23] World Cancer Research Fund - American Institute for Cancer Research. Food, nutrition, physical activity, and the prevention of cancer: a global perspective. Washington, DC; 2007.

[24] Lunet N, Lacerda-Vieira A, Barros H. Fruit and vegetables consumption and gastric cancer: a systematic review and metaanalysis of cohort studies. Nutr Cancer 2005;53(1):1-10.

[25] Karim-Kos H, de Vries E, Soerjomataram I, Lemmens V, Siesling S, Coebergh J. Recent trends of cancer in Europe: a combined approach of incidence, survival and mortality for 17 cancer sites since the 1990s. Eur J Cancer 2008;44(10):1345.

[26] Malvezzi M, Bonifazi M, Bertuccio P, Levi F, La Vecchia C, Decarli A, et al. An age-period-cohort analysis of gastric cancer mortality from 1950 to 2007 in Europe. Ann Epidemiol 2010;20(12):898-905.

[27] Chen Y, Blaser MJ. Association between gastric Helicobacter pylori colonization and glycated hemoglobin levels. J Infect Dis 2012;205(8):1195-202.

[28] Seiskari T, Viskari H, Kaila M, Haapala AM, Koskela P, Hyoty $\mathrm{H}$. Time trends in allergic sensitisation and Helicobacter pylori prevalence in Finnish pregnant women. Int Arch Allergy Immunol 2009;150(1):83-8.

[29] Broutet N, Sarasqueta AM, Cantet F, Lethuaire D, Megraud F. Is there a link between the variation in gastric cancer mortality and differences in Helicobacter pylori prevalence in different regions of France? Gastroenterol Clin Biol 1999;23(6-7):754-60.

[30] Leja M, Cine E, Rudzite D, Vilkoite I, Huttunen T, Daugule I, et al. Prevalence of Helicobacter pylori infection and atrophic gastritis in Latvia. Eur J Gastroenterol Hepatol 2012;24(12):1410-7.

[31] Ferreccio C, Rollan A, Harris PR, Serrano C, Gederlini A, Margozzini P, et al. Gastric cancer is related to early Helicobacter pylori infection in a high-prevalence country. Cancer Epidemiol Biomarkers Prev 2007;16(4):662-7.

[32] Kim JH, Kim HY, Kim NY, Kim SW, Kim JG, Kim JJ, et al. Seroepidemiological study of Helicobacter pylori infection in asymptomatic people in South Korea. J Gastroenterol Hepatol 2001;16(9):969-75.

[33] Lim SH, Kwon JW, Kim N, Kim GH, Kang JM, Park MJ, et al. Prevalence and risk factors of Helicobacter pylori infection in 
Korea: nationwide multicenter study over 13 years. BMC Gastroenterol 2013;13:104.

[34] Sasazuki S, Inoue M, Iwasaki M, Otani T, Yamamoto S, Ikeda S, et al. Effect of Helicobacter pylori infection combined with CagA and pepsinogen status on gastric cancer development among Japanese men and women: a nested case-control study. Cancer Epidemiol Biomarkers Prev 2006;15(7):1341-7.

[35] Tamura T, Morita E, Kondo T, Ueyama J, Tanaka T, Kida Y, et al. Prevalence of Helicobacter pylori infection measured with urinary antibody in an urban area of Japan, 2008-2010. Nagoya J Med Sci 2012;74(1-2):63-70.

[36] Ladeiras-Lopes R, Pereira AK, Nogueira A, Pinheiro-Torres T, Pinto I, Santos-Pereira R, et al. Smoking and gastric cancer: systematic review and meta-analysis of cohort studies. Cancer Causes Control 2008;19(7):689-701.

[37] La Vecchia C, Bosetti C, Bertuccio P, Castro C, Pelucchi C, Negri E. Trends in alcohol consumption in Europe and their impact on major alcohol-related cancers. Eur J Cancer Prev 2013. http:// dx.doi.org/10.1097/CEJ.0b013e32836562f1. [Epub ahead of print].

[38] Gallus S, Lugo A, La Vecchia C, Boffetta P, Chaloupka FJ, Colombo P, et al. Pricing Policies and Control of Tobacco in Europe (PPACTE) project: cross-national comparison of smoking prevalence in 18 European countries. Eur J Cancer Prev 2014. http://dx.doi.org/10.1097/CEJ.0000000000000009. [Epub ahead of print].

[39] Funatogawa I, Funatogawa T, Yano E. Trends in smoking and lung cancer mortality in Japan, by birth cohort, 1949-2010. Bull World Health Organ 2013;91(5):332-40.

[40] Soerjomataram I, De Vries E, Pukkala E, Coebergh JW. Excess of cancers in Europe: a study of eleven major cancers amenable to lifestyle change. Int J Cancer 2007;120(6):1336-43.

[41] Zullo A, Hassan C, Ridola L, Repici A, Manta R, Andriani A. Gastric MALT lymphoma: old and new insights. Ann Gastroenterol 2014;27(1):27-33.

[42] Kuper-Hommel MJJ, Van De Schans SAM, Vreugdenhil G, Van Krieken JHJM, Coebergh JWW. Trends in incidence, therapy and outcome of localized nodal and extranodal marginal zone lymphomas: declining incidence and inferior outcome for gastrointestinal sites. Leuk Lymphoma 2013;54(9): 1891-7.

[43] Malfertheiner P, Megraud F, O'Morain C, Atherton J, Axon A, Bazzoli F, et al. Management of Helicobacter pylori infection the Maastricht IV/Florence Consensus Report. Gut 2012;61(5):646

[44] Smalley SR, Benedetti JK, Haller DG, Hundahl SA, Estes NC, Ajani JA, et al. Updated analysis of SWOG-directed intergroup study 0116: a phase III trial of adjuvant radiochemotherapy versus observation after curative gastric cancer resection. J Clin Oncol 2012;30(19):2327-33.

[45] Cunningham D, Allum WH, Stenning SP, Thompson JN, Van de Velde CJ, Nicolson M, et al. Perioperative chemotherapy versus surgery alone for resectable gastroesophageal cancer. N Engl J Med 2006;355(1):11-20.

[46] Bang Y-J, Van Cutsem E, Feyereislova A, Chung HC, Shen L, Sawaki A, et al. Trastuzumab in combination with chemotherapy versus chemotherapy alone for treatment of HER2-positive advanced gastric or gastro-oesophageal junction cancer (ToGA): a phase 3, open-label, randomised controlled trial. Lancet 2010;376(9742):687-97.

[47] Dikken JL, Cats A, Verheij M, Van De Velde CJH. Randomized trials and quality assurance in gastric cancer surgery. J Surg Oncol 2013;107(3):298-305.

[48] De Angelis R, Sant M, Coleman MP, Francisci S, Baili P, Pierannunzio D, et al. Cancer survival in Europe 1999-2007 by country and age: results of EUROCARE-5 - a population-based study. Lancet Oncol 2014;15(1):23-34.
[49] Hiripi E, Jansen L, Gondos A, Emrich K, Holleczek B, Katalinic A, et al. Survival of stomach and esophagus cancer patients in Germany in the early 21st century. Acta Oncol 2012;51(7):906-14.

[50] Lagergren J, Mattsson F. Diverging trends in recent populationbased survival rates in oesophageal and gastric cancer. PLoS One 2012;7(7):e41352.

[51] Wu H, Rusiecki JA, Zhu K, Potter J, Devesa SS. Stomach carcinoma incidence patterns in the United States by histologic type and anatomic site. Cancer Epidemiol Biomarkers Prev 2009; 18(7):1945-52.

[52] Kaneko S, Yoshimura T. Time trend analysis of gastric cancer incidence in Japan by histological types, 1975-1989. Br J Cancer 2001;84(3):400.

[53] Pinheiro PS, Van Der Heijden LH, Coebergh JW. Unchanged survival of gastric cancer in the southeastern Netherlands since 1982: result of differential trends in incidence according to Lauren type and subsite. Int J Cancer 1999;84(1):28-32.

[54] Cho E, Kang MH, Choi KS, Suh M, Jun JK, Park EC. Costeffectiveness outcomes of the national gastric cancer screening program in South Korea. Asian Pac J Cancer Prev 2013;14(4):2533-40.

[55] Higashi T, Machii R, Aoki A, Hamashima C, Saito H. Evaluation and revision of checklists for screening facilities and municipal governmental programs for gastric cancer and colorectal cancer screening in Japan. Jpn J Clin Oncol 2010;40(11):1021-30.

[56] Boccia S, La Vecchia C. Dissecting causal components in gastric carcinogenesis. Eur J Cancer Prev 2013;22(6):489-91.

[57] Carr JS, Zafar SF, Saba N, Khuri FR, El-Rayes BF. Risk factors for rising incidence of esophageal and gastric cardia adenocarcinoma. J Gastrointest Cancer 2013;44(2):143-51.

[58] Turati F, Tramacere I, La Vecchia C, Negri E. A meta-analysis of body mass index and esophageal and gastric cardia adenocarcinoma. Ann Oncol 2013;24(3):609-17.

[59] Dikken JL, Lemmens VE, Wouters MW, Wijnhoven BP, Siersema PD, Nieuwenhuijzen GA, et al. Increased incidence and survival for oesophageal cancer but not for gastric cardia cancer in the Netherlands. Eur J Cancer 2012;48(11):1624-32.

[60] Lopez AD, Collishaw NE, Piha T. A descriptive model of the cigarette epidemic in developed countries. Tob Control 1994;3(3):242.

[61] Ng M, Freeman MK, Fleming TD, Robinson M, DwyerLindgren L, Thomson B, et al. Smoking prevalence and cigarette consumption in 187 countries, 1980-2012. JAMA 2014;311(2):183-92.

[62] La Vecchia C, Negri E, D’Avanzo B, Franceschi S. Electric refrigerator use and gastric cancer risk. $\mathrm{Br} \mathrm{J}$ Cancer 1990;62(1):136-7.

[63] Ogden CL, Carroll MD. Prevalence of overweight, obesity, and extreme obesity among adults: United States, trends 1960-1962 through 2007-2008. CDC - National Center for Health Statistics; 2010.

[64] National Health Service (NHS). International comparisons of obesity prevalence: National Obesity Observatory; 2009. Available from: http://www.noo.org.uk/securefiles/140121_1516// International Comparisons Obesity Prevalence2.pdf. [Accessed on $20 / 01 / 2014]$.

[65] WHO. Global Health Observatory (GHO) - overweight and obesity; 2013.

[66] Toneto MG, de Andrade Sehn A, Lisot BC, Lopes MHI. History of gastric cancer treatment: the pioneers, early misconceptions and the current guidelines [História do tratamento do câncer gástrico: Os pioneiros, os equívocos iniciais e os marcos de referência atuais]. Sci Med 2012;22(4):216-23.

[67] Leung WK, Wu MS, Kakugawa Y, Kim JJ, Yeoh KG, Goh KL, et al. Screening for gastric cancer in Asia: current evidence and practice. Lancet Oncol 2008;9(3):279-87. 
[68] Klein HO. Long-term results with FAMTX (5-fluorouracil, adriamycin, methotrexate) in advanced gastric cancer. Anticancer Res 1989;9(4):1025-6.

[69] Shen L, Shan Y-S, Hu H-M, Price TJ, Sirohi B, Yeh K-H, et al. Management of gastric cancer in Asia: resource-stratified guidelines. Lancet Oncol 2013;14(12):e535-47.

[70] Burke EC, Karpeh MS, Conlon KC, Brennan MF. Laparoscopy in the management of gastric adenocarcinoma. Ann Surg 1997;225(3):262-7.
[71] Webb A, Cunningham D, Scarffe JH, Harper P, Norman A, Joffe JK, et al. Randomized trial comparing epirubicin, cisplatin, and fluorouracil versus fluorouracil, doxorubicin, and methotrexate in advanced esophagogastric cancer. J Clin Oncol 1997;15(1):261-7.

[72] Songun I, Putter H, Kranenbarg EM, Sasako M, van de Velde CJ. Surgical treatment of gastric cancer: 15-year follow-up results of the randomised nationwide Dutch D1D2 trial. Lancet Oncol 2010;11(5):439-49. 